\title{
Exploring the students' adversity quotient in online mathematics learning during the Covid-19 pandemic
}

\author{
Tiara Wahyu Anggraini*, Ali Mahmudi \\ Department of Mathematics Education, Universitas Negeri Yogyakarta, Indonesia \\ *Corresponding author: tiarawahyu.2019@student.uny.ac.id
}

\section{ARTICLE INFO}

Article history:

Received: 4 February 2021

Revised: 5 June 2021

Accepted: 7 June 2021

Published online: 29 June

2021

Published regularly: July 2021

Keywords:

Adversity quotient, online mathematics learning, Covid-

19, platform

\section{ABSTRACT}

Adversity Quotient (AQ) is a person's ability to overcome difficulties someone faces. It shows how students overcome their difficulties. This study aims to describe the students' AQ in online mathematics learning during the Covid-19 pandemic era and see if there is an effect of the number of platforms used when learning on students' AQ. A survey method is used with 2093 respondents consisting of Senior High School, Islamic Senior High School, and Vocational High School students from 32 provinces in Indonesia. The instrument of the Adversity Response Profile (ARP) questionnaire consists of 30 statements with two questions each. However, two open-ended questions were given before proceeding to the ARP questionnaire. The ARP questionnaire was made in and distributed through Google Form. The results show that students' AQ in online mathematics learning was Camper. This means that the respondents were sufficient in overcoming difficulties when learning mathematics online, but they were quickly satisfied with the results which led them not to develop themselves further. Furthermore, there is no effect of the number of platforms used when learning mathematics online on the students' AQ.

(C) 2021 Universitas Muhammadiyah Surakarta

\section{Introduction}

The Covid-19 pandemic has changed the fabric of school learning systems around the world. Learning that should be done in the classroom has been done at home now. This is because schools are considered prone to viruses to reproduce, making them dangerous for students and teachers (Sintema, 2020). School closures were put in place on February 16, 2020 in parts of China and extended nationwide about a week later. Furthermore, other countries also started to close schools, but did not stop the teaching and learning process due to the widespread pandemic. By the end of March, school closures had been implemented in 46 countries. However, not all countries affected by the pandemic closed all their schools. For example, primary schools in Iceland remained open when the class size was under 20 students. In Sweden, most primary schools and junior high schools remained open while high schools were shifted to distance learning (Schleicher, 2020). 
Even though the school was closed, the teaching and learning process were still carried out. Some countries conducted distance learning using several online platforms, such as educational contents and virtual meetings conducted using video conference. Besides, some countries such as Greece, Korea, Portugal, and Spain used TV broadcasting to cater to younger students who may have difficulty using online learning platforms or independent learning. TV broadcasts can also reach students who have limited learning resources. However, they have a limited time. The lessons broadcasted cover only five subjects, such as Spanish, mathematics, social sciences, natural sciences, and arts or physical education. The TV broadcast lasts for one hour a day(Schleicher, $\underline{2020}$ ).

Various ways described above are intended for students at the elementary and junior high school levels while high schools are shifted to online learning. This of course makes it more difficult for high school students to implement online learning, especially for XII grade students who are preparing for university entrance exams (Giannopoulou, Efstathiou, Triantafyllou, Korkoliakou, \& Douzenis, 2020). Besides, high school education is the basis of any tertiary education (Hema \& Gupta, 2015). For this reason, high school student must be able to face and overcome the difficulties they are experiencing. This study is more focused on high school students who are and have been doing online learning in the pandemic era. It may be that some schools carried out online learning for only a few months, then they conducted face-to-face class because the area has been in a safe area (green zone/areas with few cases of Covid-19).

Before the Covid-19 pandemic, online-based mathematics learning had been implemented. It was used to maximize the availability of teachers who might be busy or away from students. They may set up online conferences such as live chats or webinars regularly, e.g., once a week. This can make students have easy access to communicate with teachers (Lee, 2014). There are also online tutoring platforms that students may use to study at homes, such as Zenius and Ruangguru. This online tutor features a tutor or teacher accompanied by various interesting features as suggestions to help sharpen the material presented. They provide very interesting and complete contents in materials, practice questions, discussions, quizzes, modules, summaries, and subjects. In addition, online learning can be combined with face-to-face learning called blended learning (Adnan \& Boz, 2015).

During the covid-19 pandemic, the only way for schools to keep the teaching and learning process is by implementing online learning. This consequently makes students "forced" to use the learning system because it is more effective. Daniel (ㅁ2020) stated that Covid-19is the biggest challenge for the education system which requires teachers and students to do online learning and virtual education. However, if taken on the positive side, all educational institutions are encouraged to involve technology in the teaching and learning process so that both lecturers, teachers, and students can be technology literate (Siron, Wibowo \& Narmaditya, 2020). With the transfer of the teaching and learning process from face-to-face in the classroom into online learning, it is not easy. There must be challenges and problems that occur while implementing it. Zaharah, Kirilova, and Windarti (2020) said that the obstacles in implementing elearning are that both students and teachers have not got used to implement it.

Online learning certainly requires supporting devices. Students must have the necessary digital devices such as laptops, computers, tablets, handphones, internet access, affordable internet costs, and adequate electricity supply so that they can easily take online mathematics classes (Mulenga \& Marbán, 2020). Besides, Tezer and Çimşir 
(2018) explained that several tools make it possible to support learning activities on the web, including website pages, additional software, email, forums, multimedia, virtual classroom applications, teleconferencing, and video conferencing. Roy (2020) proposed some tips that can help children learn from home during a pandemic. For example, teachers need to download several teleconferencing facilities (Skype, Zoom, or Google meet) to deliver lessons remotely. There are various platforms that teachers and students can use to support online learning. However, they need to choose which platform is the best.

Online learning is different from face-to-face learning. Moreover, mathematics learning requires teacher feedback after working on practice questions but there is limited time for reflection (Petty \& Farinde, 2013). Even worse, if the teacher only gives assignments and materials without any explanation the students will eventually find difficulties. The obstacles found during online learning include problems with the mobile phone signals, limited internet quotas, and inadequate electricity supply (Sumarna, Kansil \& Hamid, 2020; Mulenga \& Marbán, 2020; Marbán, Radwan, Radwan, \& Radwan, 2021). These obstacles certainly "forces" students to overcome them. Everyone must be different in dealing with their problems. Especially for senior high school students who have a greater sense of responsibility to assignments than elementary and junior high school students. The students will have more attention to the problems they face. They will certainly be more aware and look for ways to solve these problems. However, some students are still ignorant of the problems they face. In other words, each student has different abilities in solving problems, leading to different effects on the way he/she deals with math problems (Sari, Sutopo, \& Aryuna, 2016). How a student copes with difficulty is known as Adversity Quotient (AQ) (Stoltz, 1997).

Singh and Sharma (2017) defines AQ as a science of endurance that can measure an individual's ability to deal with difficulties in his life. This is in line with Dorji and Singh (2019) stating that AQ is a science of endurance to measure a person's ability to face difficulties in life, so that a person can turn obstacles into opportunities. Stoltz (1997) defines AQ as how a person can withstand difficulties and is able to overcome

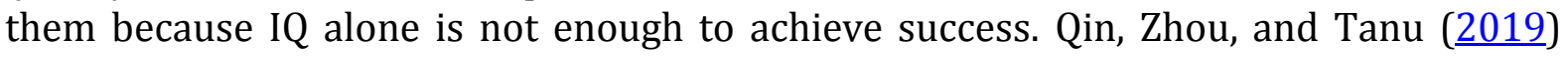
stated that AQ is one of the keys to succeed in learning mathematics. If a student has a high $\mathrm{AQ}$, he/she can easily solve math problems by trying various possibilities until the right answer is achieved. This occurs because he has endurance and never gives up on the difficulties he is facing. This is in line with Parvathy and Praseeda (2014) stating that a person who has a high AQ can achieve his goals by fighting against all obstacles that stand in his way.

Stoltz (1997) categorizes AQ into five types such as follows.

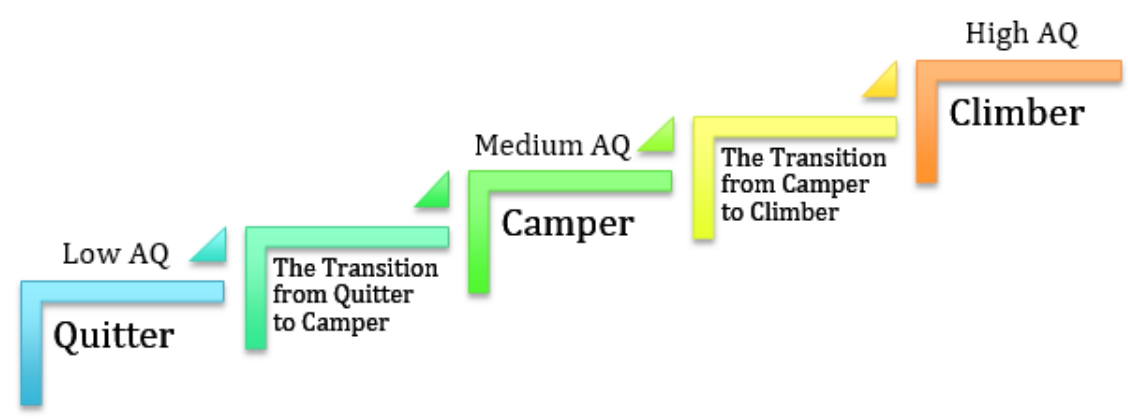

Figure 1. AQ category 
A climber is someone who always never gives up and thinks that every obstacle will not get in his way to achieve the desired success. The transition from camper to climber is someone who has endured enough to break through the challenges and exploit most of his potential, but needs to increase his effectiveness again by refining some aspects of AQ. Camper is someone who will feel easily satisfied when he has got the results. The transition from quitter to camper is someone who tends to underutilize his potential so that the difficulties he faces can caused is advantages. Meanwhile, a Quitter is someone who does not try or is not enthusiastic about achieving his goals. Besides, there are four dimensions of AQ such as follows.

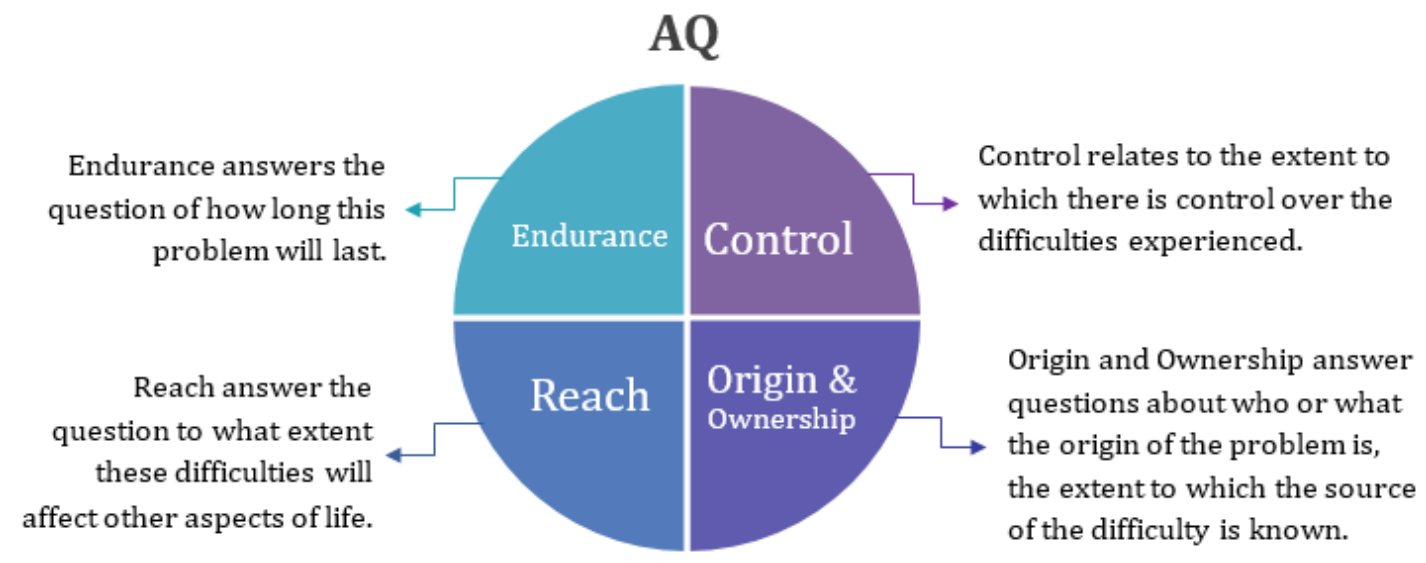

Figure 2. Four dimensions of $A Q$

A previous study that examined students' AQ in face-to-face mathematics learning in Indonesian schools was conducted by Wardani and Mahmudi (2019). They found that the average AQ of vocational students was at a medium level (camper), reaching $72 \%$ of the total sample. This shows that most of the vocational high school students' AQ is sufficient but it needs to be developed because mathematics requires high AQ in the learning process. The research by Hastuti, Sari, and Riyadi (2018) found students who have high AQ (climber) can face learning mathematics in various materials and with different learning models. The research by Darmawan, Budiyono, and Pratiwi (ㅁ19) found that students with the AQ climbers type had better mathematics learning achievement than AQ students with the campers and quitters type. Students with AQ type of camper have better mathematics achievement than students with AQ type of quitters.

What about students' AQ in online mathematics learning during the pandemic era? A study needs to be conducted to see how the students' AQ increases, decreases, or remains the same as before the pandemic era. AQ can describe how students' attitudes when facing and overcoming problems in online mathematics learning. Furthermore, is there any influence on the number of platforms used with the AQ type of students? This study was conducted because each school certainly uses one or even several different platforms when learning. This study aims to describe students' $A Q$ in online mathematics learning during the pandemic era. In addition, this study examines the effect of the number of platforms used in online learning on students' AQ. 


\section{Research Methods}

This study uses three analysis methods and a survey method. Qualitative research approach in this study is used to analyze two open-ended questions. Meanwhile, quantitative research approach in this study uses descriptive statistics analysis and simple linear regression analysis. The first analysis is used to determine the AQ category while the second is used to examine the effect of the number of online leaning platforms. The survey method in the form of the Adversity Response Profile (ARP) questionnaire was distributed through Google Form. This was done because of the Covid-19 pandemic, making it hardly possible to distribute the questionnaire to the respondent directly. The population in this study was high school students who were doing online learning during the Covid-19 pandemic. The collected sample was 2.093 students from 180 schools consisting of 128 Senior High Schools (SMA), 13 Islamic Senior High Schools (MA), and 39 Vocational High Schools (SMK). The distribution of questionnaires can be seen in Table 1 .

Table 1

Questionnaire distributions in various provinces

\begin{tabular}{|c|c|c|}
\hline Provinces & $\begin{array}{c}\text { Number of } \\
\text { Schools }\end{array}$ & Respondents \\
\hline Nanggroe Aceh Darussalam & 3 & SMA and MA \\
\hline Sumatera Utara & 2 & SMA \\
\hline Riau & 1 & SMA \\
\hline Kepulauan Riau & 3 & SMA \\
\hline Jambi & 5 & SMA and SMK \\
\hline Bengkulu & 4 & SMA and SMK \\
\hline Sumatera Selatan & 1 & SMA \\
\hline Kepulauan Bangka Belitung & 1 & SMK \\
\hline Lampung & 3 & SMA \\
\hline Banten & 3 & SMA and MA \\
\hline Jawa Barat & 14 & SMA, MA, and SMK \\
\hline DKI Jakarta & 7 & SMA and SMK \\
\hline Jawa Tengah & 22 & SMA, MA, and SMK \\
\hline DI Yogyakarta & 10 & SMA and SMK \\
\hline JawaTimur & 12 & SMA, MA, and SMK \\
\hline Bali & 2 & SMA \\
\hline Nusa Tenggara Barat & 3 & SMA \\
\hline Nusa Tenggara Timur & 2 & SMA \\
\hline Kalimantan Barat & 4 & SMA, MA, and SMK \\
\hline Kalimantan Selatan & 3 & SMA \\
\hline Kalimatan Tengah & 3 & SMA \\
\hline Kalimantan Timur & 4 & SMA and SMK \\
\hline Kalimatan Utara & 5 & SMK \\
\hline Gorontalo & 3 & SMA, MA, and SMK \\
\hline Sulawesi Barat & 1 & SMA \\
\hline Sulawesi Selatan & 8 & SMA and SMK \\
\hline Sulawesi Tengah & 38 & SMA, MA, and SMK \\
\hline Sulawesi Tenggara & 2 & SMA \\
\hline Maluku & 4 & SMA and SMK \\
\hline Maluku Utara & 3 & SMA \\
\hline Papua Barat & 2 & SMA \\
\hline Papua & 2 & SMA and MA \\
\hline
\end{tabular}

The distribution of questionnaire in every province in Indonesia was uneven. Therefore, this study used an incidental sampling technique, where anyone who had filled out a 
questionnaire and was deemed suitable as a data source was the subject who was sampled.

Data collection was carried out online using an Adversity Response Profile (ARP) questionnaire made in and distributed through Google Form. The ARP questionnaire contained 30 statements with two questions each. The ARP questionnaire used a Semantic Differential scale which was in a continuous line. The answer on the far right was very positive while the answer on the far left was very negative answer. Before students filled out the ARP questionnaire, students were given two open-ended questions. The two questions were related to what platform to use when learning online and how to teach math if they only used the Chat application platform, such as WhatsApp.

The indicators used in the ARP questionnaire consisted of 4 dimensions of Control, Origin and Ownership, Reach, and Endurance. The instrument was adapted from the instruments made by Stoltz (1997) with some adjustments to the characteristics of high school students. Besides, this instrument had been validated by expert judgment and the reliability value was calculated, namely the Cronbach alpha value $0.837>0.361(\mathrm{r}$ table) (Stevens, 2002); thus, it was valid and reliable. Data from the ARP questionnaire was used to group students according to their AQ level. Stoltz (1997) categorized students' AQ based on the results of the ARP score (see Table 2).

\section{Table 2}

AQ category based on ARP score

\begin{tabular}{ccl}
\hline No & Score & \multicolumn{1}{c}{ Student Category } \\
\hline 1. & $0-59$ & Quitter (QT) \\
2. & $60-94$ & The transition from quitter to camper (QT - CP) \\
3. & $95-134$ & Camper (CP) \\
4. & $135-165$ & The transition from camper to climber (CP - CB) \\
5. & $166-200$ & Climber (CB) \\
\hline
\end{tabular}

As previously explained, before the students filled out the ARP questionnaire, they were first given two open-ended questions. The two questions are:

1. What platforms are used for online learning at your school?

2. If WhatsApp is chosen, what learning methods do math teachers have? (Example: a learning material video is sent)

These two questions are asked to find out what platforms are used when learning online and to investigate whether there is an effect of the number of platforms used on students' AQ. The results were then analyzed in a qualitative approach with data analysis technique by Miles, Huberman, and Saldaña (2014).This technique used three stages, namely data condensation, data display, and conclusion drawing/verification. To determine the effect of the number of platforms for online learning on students' AQ, simple linear regression analysis in SPSS 21 software was used.

\section{Results and Discussion}

\section{Two Open-ended Questions}

Two open-ended questions were analyzed using data analysis techniques by Miles, Huberman, and Saldaña (2014). This analysis used three stages, namely: data condensation, data presentation, and conclusion drawing/verification. The results of the analysis are as follows. 
What platforms are used for online learning at your school?

The results of this study show that there are various platforms used by schools in Indonesia which are categorized as follows: Learning Management System, Video Conference, Chat Application, Video Application, and other platforms. Most schools do not only use one platform for online learning. For example, there is a school using Zoom and WhatsApp, in which Zoom is used for online learning, teaching and learning processes, and discussions while WhatsApp is used for notification regarding the Zoom link which will be used as a classroom or as a place to collect student assignments. However, some schools use one platform, for example, WhatsApp or Google classroom only.

Table 3

Profile of respondents

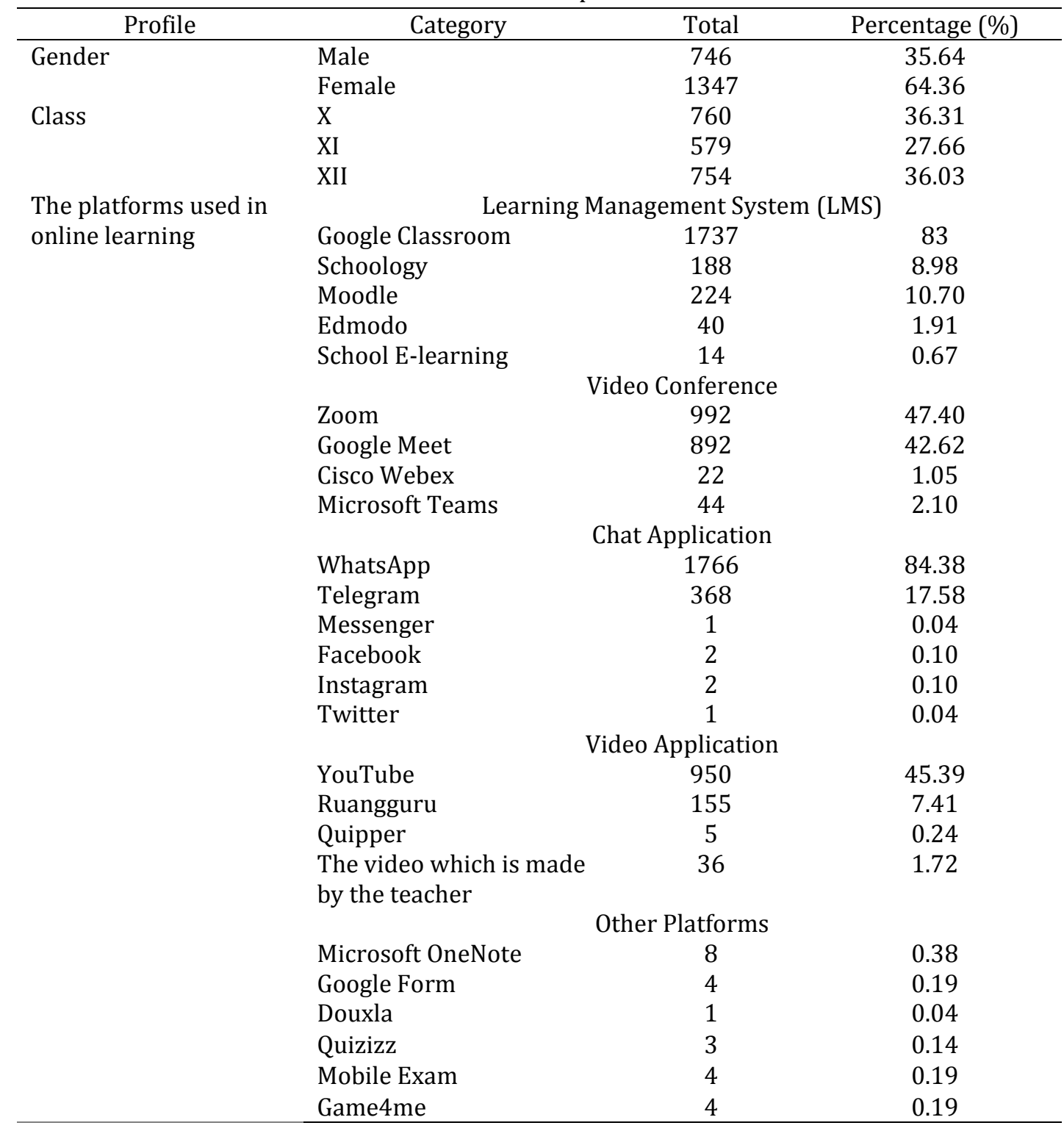

Table 3 shows that 746 (35.46\%) respondents are female, while 1347 (64.36\%) respondents are male. Respondents were the samples, consisting of Grade X, XI, and XII of high schools in Indonesia. For teaching and learning activities, teachers used various platforms of the Learning Management System (LMS) including Google Classroom, 
Schoology, Moodle, Edmodo, and School E-Learning. For video conference, teachers used Zoom, Google Meet, Cisco Webex, and Microsoft Teams. For chatting, teachers used WhatsApp, Telegram, Messenger, Facebook, Instagram, and Twitter. For video sharing, teachers used YouTube, Ruang Guru, and Quipper. In addition, some teachers used Microsoft OneNote, Google Form, Douxla, Quizizz, Mobile Exam, and Game4me for additional teaching-learning platform.

The most widely used platform by schools is Google Classroom (83\%) for LMS, Zoom $(47,40 \%)$ and Google Meet $(42,62)$ for video conference, WhatsApp $(84,38 \%)$ for chat application, and YouTube $(45,39 \%)$ for video application. In fact, most of these platforms support each other. WhatsApp was used as a notification, while Google Classroom was used as a place to deliver the materials, distribute questions, and collect assignments. Zoom and Google Meet were used as a media for face-to-face learning, while YouTube was used to embed videos of the material uploaded on their personal or school YouTube account. In this case, teachers can also take and send video material related to students by sending the video link to WhatsApp. However, there are some schools that only use one of the aforementioned platforms.

Figure 3 shows that there are 7 most platforms used during online learning. Teachers use several platforms that support each other to make the teaching and learning process easier and more effective. It can be seen that 387 students stated that they only used one platform when learning online. Some used only LMS such as Google Classroom, and some only use chat applications such as WhatsApp or Telegram. Furthermore, 330 students stated that they used two platforms in learning for the red chart, such as WhatsApp and Google classroom or WhatsApp and Zoom. Then, 613 students used three platforms in their learning for the yellow chart, namely: LMS, chat applications, and video conference apps. Furthermore, most students used four platforms for the green chart (485 students), followed with five platforms for the orange chart (193 students), six platforms for the tosca chart (81 students), and seven platforms in their learning for the purple chart (4 students). For more than five platforms, in addition to using LMS, video conference, and chat applications, some schools use video applications or platforms that support playing while studying such as Quizizz or online exams.

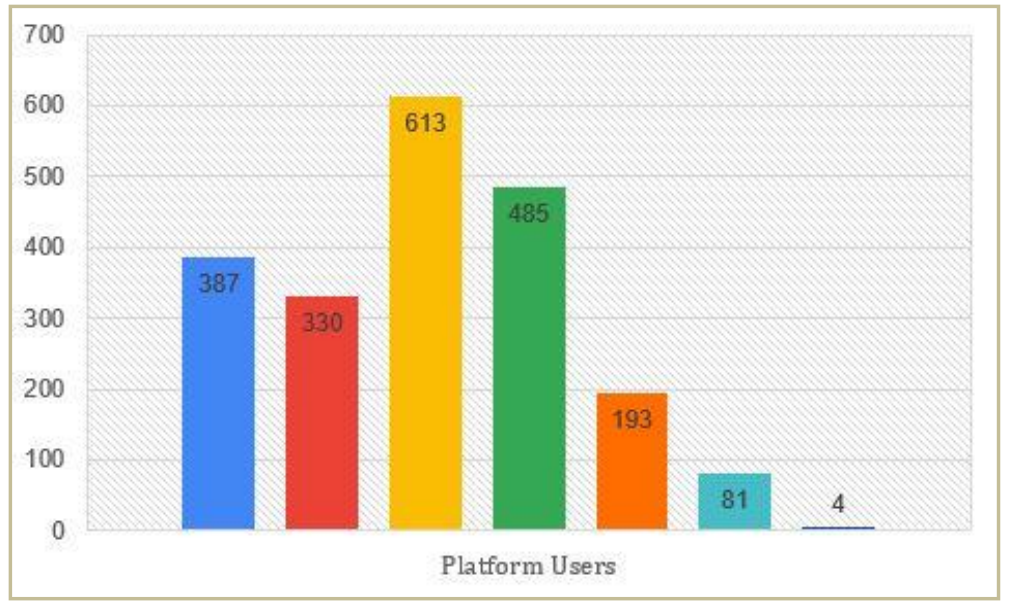

Figure 3. Platform users in schools

. The survey results state that the three platforms are the most widely used in online learning. On average, three platforms consist of the chat application, video conference, and the Learning Management System (LMS). These three platforms are 
most widely used by schools because they are considered very supportive in online learning. Besides, there are also schools that only use one platform, either the LMS or a chat application. This is in line with the study by Mulenga and Marbàn (ㅁ2020) stating that the most widely used platforms were YouTube of $97 \%$ (Video application) and WhatsApp of $94.1 \%$ (Chat application). In this study, pre-teachers used YouTube to browse learning videos about math concepts, while they used WhatsApp to get help with math/homework/research assignments.

\section{If WhatsApp is chosen, what learning methods do math teachers have?}

The most widely used platform is WhatsApp (Chat application). It is an application which does not require a large data package and is easier to use. Besides, it is widely used at schools located in somewhat remote areas (districts) which the network connection is limited. This is in line with the research by Wargadinata, Maimunah, Dewi, and Rofiq (2020) stating that the most widely used application in online learning is WhatsApp since it is easy, simple, and does not require a large data. In addition, through the WhatsApp account, learning takes place optimally because students and lecturers can communicate and share PowerPoint files, Microsoft Word files, JPGs, Voice Notes, Videos, and other learning resource links. Afterwards, the analysis went further to the learning method used by Math teacher in the learning process through WhatsApp. The results of online Mathematics learning through WhatsApp are summarized below.

- As tool for announcements and reminders. Chat applications, such as WhatsApp, are not the only platforms used at several schools, since there are several other platforms used such as Google Classroom, Zoom, Google Meet, YouTube, etc. Here, WhatsApp is used as a place for notifications and reminders such as to send a Zoom or Google Meet link, as a list of attendees, and for notification of exam results.

- As a tool to send material such as ppt files, modules, videos from YouTube, and photos of material from books or the writings of the teacher. For YouTube videos, teachers usually make videos of math material and then upload them to their personal YouTube account or school YouTube account. Some teachers only take videos related to Math material on YouTube and send the link to WhatsApp.

- As a tool to send assignments if the school does not use the Learning Management System (LMS) platform.

- As a tool for discussion. Several schools only use WhatsApp application as a platform for online learning. Therefore, WhatsApp is used as a place for discussion, question and answer, and giving feedback from the teacher regarding the material studied.

However, there is additional information obtained regarding the use of WhatsApp as a platform used in online learning. When learning online, the teacher sends material in PPT or PDF file then continues with the teacher's explanation using voice notes or written chats. Some teachers make video calls to explain the material, and some make videos and then send them on the WhatsApp group so that students better understand the material they are learning. However, it cannot be denied that some teachers only send PPT or PDF files but do not provide explanations either in the form of voice notes or written chats, which confuse students with the material they are learning. Then, some teachers give games before they learn so that students can concentrate more when studying.

Based on the results found from questions number 1 and 2, it can be concluded that most SMA, MA, and SMK do not only use one platform in online learning. Most of the teachers use three platforms to support learning, such as chat applications (WhatsApp), LMS (Google Classroom), and video conference (Google Meet). WhatsApp 
is used to share a link redirected to Google Meet and Google Classroom is used for assigning and submitting assignments, but Google Meet is used for carrying out the teaching and learning process. However, the most widely used platform is WhatsApp. This is in line with the findings of Sumarna et al. (2020) stating that the three most dominant platforms used by students when learning online were Zoom, Google Classroom, and WhatsApp. In online learning, WhatsApp is used for announcements and reminders for students, a tool to send material such as ppt files, modules, videos from YouTube, etc. In addition, WhatsApp is also used asa tool for discussion and send assignments if the school does not use the Learning Management System (LMS) platform.

\section{Determine students' AQ category}

After the students answered the two open-ended questions, they were directed to fill out the ARP questionnaire. The results were then categorized as can be seen in Table 4. There are five categories of students in overcoming difficulties based on Adversity Quotient (AQ): low AQ (Quitter), the transition from Quitter to Camper, medium AQ (Camper), the transition from Camper to Climber, and high AQ (Climber). The study results obtained are based on descriptive statistics (see Table 4).

Table 4

Descriptive statistics of AQ students

\begin{tabular}{ccccccc}
\hline & N & Min & Max & Sum & Mean & Std. Deviation \\
\hline AQ & 2093 & 48 & 200 & 264604 & 126.42 & 16.515 \\
Valid N (listwise) & 2093 & & & & & \\
\hline
\end{tabular}

Table 4 showed that the lowest student AQ score obtained was 48 and the highest student AQ one was 200. The average score was 126.42, meaning that students are generally in the Camper (medium) category. It can be interpreted that they can overcome the problems they faces, but are quickly satisfied with the results what they did so that they do not develop further. For example, when learning mathematics online, there are questions that the teacher gives many solutions. However, students who have $\mathrm{AQ}$ will solve the problem but only in one way; they thought that there was no need to bother anymore to look for other solutions.

Furthermore, the students' AQ based on their Province is shown in Table 5.

Table 5

Student AQ is categorized by province

\begin{tabular}{lcc}
\hline \multicolumn{1}{c}{ Province } & $\begin{array}{c}\text { Average AQ } \\
\text { score of students }\end{array}$ & Category of AQ students \\
\hline Nanggroe Aceh Darussalam & 121.90 & Camper \\
Sumatera Utara & 127 & Camper \\
Riau & 136 & The transition from Camper to Climber \\
Kepulauan Riau & 129.93 & Camper \\
Jambi & 133.89 & Camper \\
Bengkulu & 125.69 & Camper \\
Sumatera Selatan & 124.69 & Camper \\
Kepulauan Bangka Belitung & 127 & Camper \\
Lampung & 134.07 & Camper \\
Banten & 134.19 & Camper \\
Jawa Barat & 125.78 & Camper \\
DKI Jakarta & 129.77 & Camper \\
Jawa Tengah & 126.94 & Camper \\
DI Yogyakarta & 129.53 & Camper \\
\hline
\end{tabular}


Tabel 5 (Continued)

\begin{tabular}{lcc}
\hline \multicolumn{1}{c}{ Province } & $\begin{array}{c}\text { Average AQ } \\
\text { score of students }\end{array}$ & Category of AQ students \\
\hline JawaTimur & 130.63 & Camper \\
Bali & 128.38 & Camper \\
Nusa Tenggara Barat & 119.77 & Camper \\
Nusa Tenggara Timur & 126.36 & Camper \\
Kalimantan Barat & 118.98 & Camper \\
Kalimantan Selatan & 125.95 & Camper \\
Kalimatan Tengah & 124.54 & Camper \\
Kalimantan Timur & 125.54 & Camper \\
Kalimatan Utara & 125.72 & Camper \\
Gorontalo & 118 & Camper \\
Sulawesi Barat & 121.42 & Camper \\
Sulawesi Selatan & 124.30 & Camper \\
Sulawesi Tengah & 126.37 & Camper \\
Sulawesi Tenggara & 125.31 & Camper \\
Maluku & 126.47 & Camper \\
Maluku Utara & 134 & Camper \\
Papua Barat & 129.17 & Camper \\
Papua & 119.64 & Camper \\
\hline
\end{tabular}

Table 5 shows that there are only students from 32 provinces that filled out the questionnaire. while the students from the other two provinces did not complete the questionnaire, such as Sumatra Barat and Sulawesi Utara provinces. The results of AQ show that based on the province, the average students' AQ is in the AQ Camper level or medium. Therefore, there is no difference in students' AQ when viewed from each province.

Table 6

Descriptive statistics of AQ based on education level

\begin{tabular}{clcccccc}
\hline No & & N & Min & Max & Sum & Mean & Std. Deviation \\
\hline 1. & Students' AQ of SMA & 1608 & 62 & 200 & 203335 & 126.45 & 15.966 \\
2. & Students' AQ of MA & 63 & 84 & 188 & 8033 & 127.51 & 18.053 \\
3. & Students' AQ of SMK & 422 & 48 & 200 & 53236 & 126.15 & 18.278 \\
\hline
\end{tabular}

Table 7

Descriptive statistics AQ based on the level of class

\begin{tabular}{clcccccc}
\hline No & & N & Min & Max & Sum & Mean & Std. Deviation \\
\hline 1. & Students' AQ of Grade X & 760 & 48 & 200 & 95789 & 126.04 & 16.360 \\
2. & Students' AQ of Grade XI & 579 & 80 & 193 & 72903 & 125.91 & 15.513 \\
3. & Students' AQ of Grade XII & 754 & 62 & 200 & 95916 & 127.21 & 17.389 \\
\hline
\end{tabular}

Table 8

Descriptive statistics AQ based on students' gender

\begin{tabular}{clcccccc}
\hline No & & N & Min & Max & Sum & Mean & Std. Deviation \\
\hline 1. & AQ of Male Students & 746 & 48 & 200 & 94199 & 126.27 & 17.135 \\
2. & AQ of Female Students & 1347 & 62 & 200 & 170405 & 126.51 & 16.168 \\
\hline
\end{tabular}

Furthermore, if students' $\mathrm{AQ}$ is categorized based on education levels, such as SMA, MA, and SMK as shown in Table 6, each student's average AQ score is at the Camper (medium) level. This shows that there is no difference between AQ of SMA, MA, and SMK students. Thus, it can be concluded that students' AQ based on education level does not affect students' AQ. Then, if students' AQ is categorized based on grade levels, such as Grade X, Grade XI, and Grade XII as seen in Table 7, each of the students' average 
$\mathrm{AQ}$ scores is also at the medium or Camper level. This means that there is no differences between AQ of Grade X, XI and XII students. Thus, it can be concluded that students' AQ based on grade level also does not affect students' AQ. If the students' AQ is categorized based on gender (see Table 8), both female and male respondents are at the Camper level. Thus, it can be concluded that there is no difference between the AQ of male and female students.

Figure 4 shows the five AQ categories of students in online mathematics learning, namely: climber (high AQ), the transition from camper to climber, camper (medium $A Q$ ), the transition from quitter to camper, and quitter (low AQ). It is shown that most of the samples were in the camper category (medium AQ) with a percentage of $73 \%$. For the transition from camper to climber category, a percentage of $23 \%$ was obtained. For the climber category (high AQ) and the transition from quitter to camper category obtained the same percentage, i.e., 2\%. Meanwhile, the quitter category (low AQ) obtained a percentage of $0 \%$.

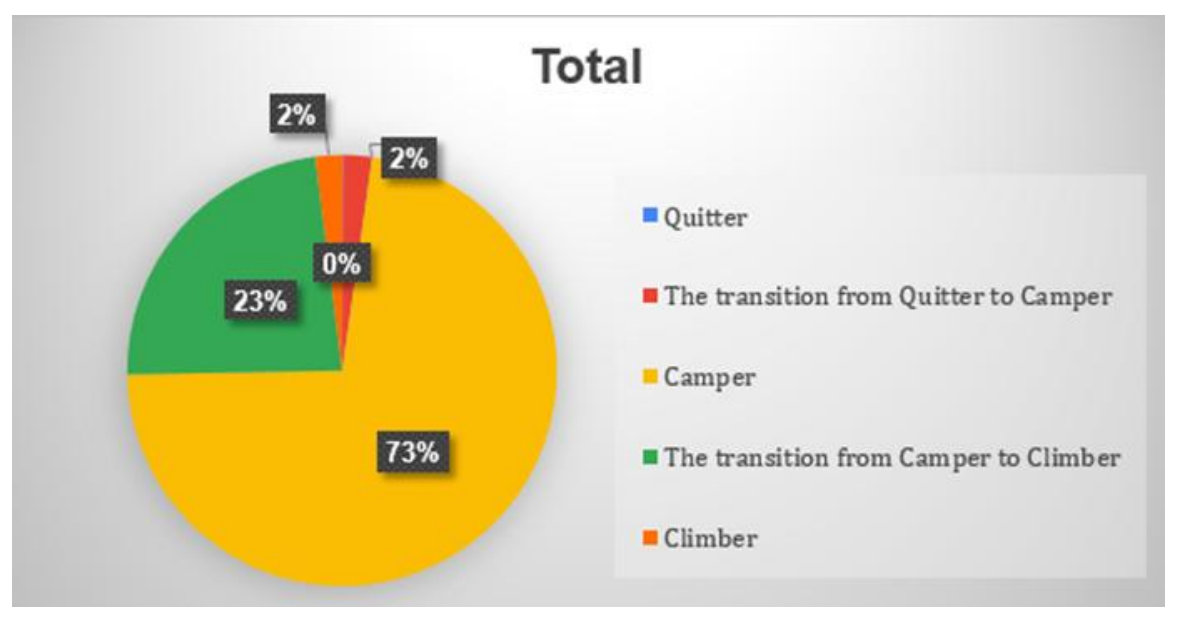

Figure 4. Students' AQ chart based on the Stoltz (1997) category

\section{Climber}

Students are categorized as AQ climbers if their AQ score ranges between 166200. This category is indicated with someone who never gives up, can control himself during at difficult situation, always thinks about the possibilities that occur, and can pass all obstacles (Stoltz, 1997). Based on the study results, 2\% or 42 of 2093 students have an adversity quotient at this level. It can be concluded that there are still few students who have high AQ. Even though students need to have a high AQ to achieve high learning achievement (Hastuti et al., 2018), they can overcome obstacles in mathematics online learning. Mathematics learning certainly requires a high $A Q$ because it requires deep understanding, reasoning, critical thinking, problem-solving, and several other abilities.

\section{The Transition from Camper to Climber}

Students are categorized as AQ transition from camper to climber if the AQ score ranges between 135-165. Those with this AQ have the potential to move up to the AQ climber. Therefore, they can further increase their potential and mindset towards the opportunities that exist in the obstacles they find (Stoltz, 1997). Based on the study results, $23 \%$ or 487 of 2093 students have an adversity quotient at this level. It means 
that Indonesian high school students in the AQ category can move up to the AQ category of climber. Thus, they need to improve some aspects of their AQ. Increasing AQ to the climber can make them think more positively when overcoming difficulties, especially when working on math problems. They will not be easily satisfied when they can solve the problem, so they can try other ways to answer.

\section{Camper}

Students are categorized as AQ campers if their AQ score ranges between 95-134. Those with this category mean that they are satisfied with their results (Stoltz, 1997). Based on the study results, 73\% or 1517 out of 2093 students have an adversity quotient at this level. Most of Indonesia's high school students fall into this category. In previous studies, the average students' AQ was also found in this category. It means that students' attitude and mindset towards an obstacle are that they struggle to solve math problems. They are satisfied with the results obtained even though they could answer the problem in other ways. In this case, the students' AQ in this category is sufficient, but it is better to improve it because learning mathematics requires high endurance.

\section{The Transition from Quitter to Camper}

Students categorized as AQ transition from quitter to camper when their score ranges between 60-94. Those with this AQ have the potential to move up to AQ camper. Students in this category mean that they tend to underutilize their potential so that the difficulties they face can cause losses (Stoltz, 1997). Based on the study results, 2\% or 46 out of 2093 students have an adversity quotient at this level. It means that students in this category should make more efforts to raise their AQ and turn their obstacles into opportunities. In learning mathematics, they should be more enthusiastic about solving math problems and must be able to avoid and overcome laziness, complaining and hopelessness. By the time, the students' AQ can move to the AQ camper.

\section{Quitter}

Students are categorized as AQ quitters if their AQ score is 59 or below. A student with this category means that he does not have the effort or enthusiasm to achieve his goals (Stoltz, 1997). Based on the study results, $0 \%$ or 1 of 2093 students has an adversity quotient at this level. It means that almost no students are in this category. One student in this category can be said to be a student who is very lazy and lacks motivation. He/she chooses to avoid obligations, resign, and stop at that point. In mathematics learning, students in this category are lazy and think that they are incapable and unable to do the Math problems given. Thus, they are just waiting for an answer from their friend or maybe not doing it at all.

Based on the results found, students' Adversity Quotient (AQ) in online mathematics learning is in the camper category (medium). If students' AQ is based on province, education level, grade level, and gender, they are also in the Camper category. Therefore, it can be said that students' AQ is sufficient. For this reason, it is necessary to have motivation and input from teachers and parents to have students change their attitudes and mindsets towards the obstacles they find and turn them into opportunities. The role of schools is also very important in managing and providing student activities that can help the students get more activities to increase their AQ (Pangma, Tayraukham \& Nuangchalerm, 2009). Besides, fortunately in online mathematics learning, it turns out that only one student has an AQ quitter. This indicates that although online mathematics learning is difficult to undertake, most high school students do not give up and continue to carry out their obligations to learn 
mathematics. Based on the five AQ categories, to see the AQ category of students clearly is focused on three categories, namely: Climber (high AQ), Camper (medium AQ), and Quitter (low AQ), to see the differences clearly. Meanwhile, the transition category was not taken because it would make the difference vague and unclear.

The influence of the number of platforms

To determine the number of platforms used on students' AQ categories, a simple linear regression test is analyzed in SPSS 21 software.

Table 9

The results of regression test analysis (Model Summary)

\begin{tabular}{ccccc}
\hline Model & $\mathrm{R}$ & R Square & $\begin{array}{c}\text { Adjusted R } \\
\text { Square }\end{array}$ & $\begin{array}{c}\text { Std. Error of } \\
\text { the Estimate }\end{array}$ \\
\hline 1 & $0.110^{\mathrm{a}}$ & 0.012 & -0.018 & 1.448 \\
\hline
\end{tabular}

a. Predictors: (Constant), Number of Platforms

Table 9 shows the value of the correlation/relationship (R) of 0.110 .It also shows the significance of the effect of the independent variable on the dependent variable, or the coefficient of determination as the result of $R^{2}$. Determination $\left(R^{2}\right)$ of 0.012 means that the effect of the independent variables (number of platforms) on the dependent variable (AQ category) is approximately 1.2\%.Therefore, it can be interpreted that the independent variable has a contribution effect of $1.2 \%$ on the dependent variable.

Table 10

The results of regression test analysis (ANOVA ${ }^{\mathrm{a}}$ )

\begin{tabular}{|c|c|c|c|c|c|c|}
\hline Model & & $\begin{array}{c}\text { Sum of } \\
\text { Squares }\end{array}$ & $\mathrm{df}$ & Mean Square & $\mathrm{F}$ & Sig. \\
\hline \multirow[t]{3}{*}{1} & Regression & 0.853 & 1 & 0.853 & 0.407 & $0.528^{b}$ \\
\hline & Residual & 69.147 & 33 & 2.095 & & \\
\hline & Total & 70.000 & 34 & & & \\
\hline
\end{tabular}

a. Dependent Variable: AQ Category

b. Predictors: (Constant), Number of Platforms

Table 10 shows that $F$ counts is 0.407 with a significance level of $0.528>0.05$.Thus, the regression model cannot be used to predict the AQ category of students.

Table 11

The results of regression test analysis (Coefficients ${ }^{\mathrm{a}}$ )

\begin{tabular}{|c|c|c|c|c|c|}
\hline \multirow[b]{2}{*}{ Model } & \multicolumn{2}{|c|}{ Unstandardized Coefficients } & \multirow{2}{*}{$\begin{array}{c}\begin{array}{c}\text { Standardized } \\
\text { Coefficients }\end{array} \\
\text { Beta }\end{array}$} & \multirow[b]{2}{*}{$\mathrm{t}$} & \multirow[b]{2}{*}{ Sig. } \\
\hline & $\mathrm{B}$ & Std. Error & & & \\
\hline (Constant) & 3.089 & 0.282 & & 10.959 & 0.000 \\
\hline Number of Platforms & -0.001 & 0.002 & -0.110 & -0.638 & 0.528 \\
\hline
\end{tabular}

a. Dependent Variable: AQ Category

Table 11 shows that the constant (a) is 3.089 , while the value of the number of platforms (b) is -0.001 . Thus, the regression equation can be written as follows:

$$
Y=3.089-0.001 X
$$

The equation above shows that the constant value is 3.089. Mathematically, this constant value states that if the value of the number of platforms is 0 , the AQ category of students has a value of 3.089. Furthermore, the negative value $(0.001)$ in the regression coefficient of the independent variable (number of platforms) illustrates that the direction of the relationship between the independent variable (number of platforms) 
and the dependent variable (AQ category) is opposite. This means each increase of one variable unit on the number of platforms will not cause the increase in the AQ category. In addition, Table 11 shows a significance value of $0.528>0.05$. Meanwhile, when viewed from the $t$-value obtained, it is $-0.638<2.035$, and it can be concluded that the number of platforms does not affect the AQ category of students.

Based on the explanation above, it can be concluded that students' AQ in online mathematics learning is categorized as medium or Camper. These results are in line with those of students' AQ in face-to-face learning, where the average students' $A Q$ obtained is also in the AQ Camper category or medium (Wardani \& Mahmudi, 2019; Darmawan et al., 2019; Bennu \& Akina, 2019; Aulia et al., 2020). In addition, there is no difference in the result when the students' AQ is categorized by province, education level, class level, or gender, i.e., AQ Camper. The same results were obtained in previous studies, showing that there was no difference between the AQ of male and female students (Nikam \& Uplane, 2013; Hema \& Gupta, 2015). Furthermore, there is also no effect of the number of platforms used when learning mathematics online with students' $A Q$. This implies that AQ of the high school students during online and face-to-face learning have the same AQ category level, i.e., AQ Camper (medium). In addition, the AQ category of students is not affected by the number of platforms used in online learning.

Based on the results, the teacher can motivate students to learn mathematics to increase students' AQ. Mathematics learning will be more interesting if the teacher creates a learning model that challenges students to compete to answer math questions such as games or quizzes so that learning is not dull and monotonous. One application that can support online math learning is Quizizz. To help students who have difficulty learning mathematics, teachers can approach students and better understand the material. Teachers can also use the peer tutoring method to help students who do not understand mathematics material. Sometimes students cannot understand the subject matter and the explanations by the teacher in class, while their friends can explain them in simple words to understand it more quickly (Nawaz \& Rehman, 2017). Students must also make more efforts to improve their AQ again by not giving up easily when solving problems and always being optimistic about what they experience.

\section{Conclusion}

The results of this study show that students' AQ in online mathematics learning is at AQ Camper (medium). This means that SMA, MA, and SMK students in Indonesia are sufficient in overcoming difficulties when learning mathematics online. However, they are quickly satisfied with the results they do and do not develop further themselves. Furthermore, there is no effect of the number of platforms used when learning mathematics online on the students' AQ. Either one type of platform or several platforms are used, the AQ level of students is still the same category, i.e., Camper. This implies that $\mathrm{AQ}$ of high school students during online and face-to-face learning have the same AQ category level, i.e., AQ Camper (medium). In addition, the AQ category of students is not affected by the number of platforms used in online learning. For further study, it is recommended that when taking the sample, it should be more proportional based on each province, education level, and grade level so that the results obtained are more representative of the population. 


\section{Acknowledgment}

We sincerely thank all Senior High School, Islamic High School, and Vocational High School students in Indonesia for giving permission and the opportunity to carry out this study.

\section{Bibliography}

Adnan, M., \& Boz, B. (2015). Faculty Members' Perspectives on Teaching Mathematics Online: Does Prior Online Learning Experience Count? Turkish Online Journal of Qualitative Inquiry, 6(61), 21-39.

Aulia, N. N., Usodo, B., \& Saputro, D. R. S. (2020). The Level of Aspects of CO2RE (Control, Origin and Ownership, Reach, Endurance) in Camper Students. International Journal of Multicultural and Multireligious Understanding, 7(1), 815-820.

Bennu, S., \& Akina, A. (2019). Development of adversity quotient based geometry learning model for prospective teachers. International Journal on Teaching and Learning Mathematics, 2(2), 60. https://doi.org/10.18860/ijtlm.v2i2.9352

Daniel, S. J. (2020). Education and the COVID-19 pandemic. Prospects. https://doi.org/10.1007/s11125-020-09464-3

Darmawan, M., Budiyono, B., \& Pratiwi, H. (2019). Mathematics learning achievement of vocational high school students' viewed by adversity quotient. International Conference on Mathematics and Science Education (ICMScE), 1-8. https://doi.org/10.1088/1742-6596/1157/4/042121

Dorji, R., \& Singh, K. (2019). Role of Adversity Quotient in Learning. UGC Approved Journal (S.No.46229) ISSN, 11(46229), 2347-4343. Retrieved from http://ijoe.vidyapublications.com

Giannopoulou, I., Efstathiou, V., Triantafyllou, G., Korkoliakou, P., \& Douzenis, A. (2020). Adding stress to the stressed: Senior high school students' mental health amidst the COVID-19 nationwide lockdown in Greece. Psychiatry Research, (November), 1-5. https://doi.org/10.1016/i.psychres.2020.113560

Hastuti, T. D., Sari, D. R., \& Riyadi. (2018). Student profile with high adversity quotient in math learning. Journal of Physics: Conference Series, 983(1). https://doi.org/10.1088/1742-6596/983/1/012131

Hema G., \& Dr. Sanjay M. Gupta. (2015). Adversity Quotient for Prospective Higher Education. International Journal of Indian Psychology, 2(3). https://doi.org/10.25215/0203.080

Lee, J. (2014). An exploratory study of effective online learning: Assessing satisfaction levels of graduate students of mathematics education associated with human and design factors of an online course. International Review of Research in Open and Distributed Learning, 15(1), 111-132. https://doi.org/https://doi.org/10.19173/irrodl.v15i1.1638

Marbán, J. M., Radwan, E., Radwan, A., \& Radwan, W. (2021). Primary and secondary students' usage of digital platforms for mathematics learning during the COVID-19 outbreak: The case of the Gaza strip. Mathematics, 9(2), 1-21. https://doi.org/10.3390/math9020110

Miles, M. B., Huberman, A. M., \& Saldaña, J. (2014). Qualitative Data Analysis A Methods Sourcebook (3 ed.). Sage Publication.

Mulenga, E. M., \& Marbán, J. M. (2020). Is COVID-19 the Gateway for Digital Learning in Mathematics Education? Contemporary Educational Technology. https://doi.org/10.30935/cedtech/7949 
Mulenga, E. M., \& Marbàn, J. M. (2020). Social media usage among pre-service secondary mathematics teachers in Zambia. JRAMathEdu (Journal of Research and Advances in $\begin{array}{lll}\text { Mathematics } \quad \text { Education), 130-147. } & \text { 5(2), }\end{array}$ https://doi.org/10.23917/jramathedu.v5i2.9920

Nawaz, A., \& Rehman, Z. (2017). Strategy of Peer Tutoring and Students Success in Mathematics: An Analysis: searches the contents of 400+ databases \&amp; publishers (7 million+ sources). Journal of Research \& Reflections in Education, 11(1), 15-29.

Nikam, V. B., \& Uplane, M. M. (2013). Adversity Quotient and Defense Mechanism of Secondary School Students. Universal Journal of Educational Research, 1(4), 303308. https://doi.org/10.13189/ujer.2013.010405

Pangma, R., Tayraukham, S., \& Nuangchale, P. (2009). Causal Factors Influencing Adversity Quotient of Twelfth Grade and Third-Year Vocational Students. Journal of Social Sciences, 5(4), 466-470. https://doi.org/10.3844/jssp.2009.466.470

Parvathy, U., \& Praseeda, M. (2014). Relationship between Adversity Quotient and Academic Problems among Student Teachers. IOSR Journal Of Humanities And Social Science (IOSR-JHSS), 19(11), 23-26.

Petty, T., \& Farinde, A. a. (2013). Investigating student engagement in an online mathematics course through Windows into Teaching and Learning. MERLOT Journal of Online Learning and Teaching, 9(2), 261-270.

Qin, L., Zhou, Y., \& Tanu, W. T. (2019). The Analysis of Mathematics Adversity Quotient of Left Behind Junior High School Students in Rural Areas. Open Journal of Social Sciences, 07(10), 331-342. https://doi.org/10.4236/jss.2019.710028

Roy, D. (2020). Trying to homeschool because of coronavirus? Here are 5 tips to help your child learn, (March). Retrieved from https://theconversation.com/trying-tohomeschool-because-of-coronavirus-here-are-5-tips-to-help-your-child-learn$\underline{133773}$

Sari, C. K., Sutopo, \& Aryuna, D. R. (2016). The Profile of Students' Thinking in Solving Mathematics Problems Based on Adversity Quotient. JRAMathEdu Uournal of Research and Advances in Mathematics Education), 1(1), 36-48. https://doi.org/10.23917/jramathedu.v1i1.1784

Schleicher, A. (2020). The impact of COVID-19 on education: Insights from education at a glance 2020. OECD Journal: Economic Studies, 1-31.

Singh, S., \& Sharma, T. (2017). Affect of Adversity Quotient on the Occupational Stress of IT Managers in India. In Procedia Computer Science. https://doi.org/10.1016/j.procs.2017.11.345

Sintema, E. J. (2020). Effect of COVID-19 on the performance of grade 12 students: Implications for STEM education. Eurasia Journal of Mathematics, Science and Technology Education, 16(7), 1-6. https://doi.org/10.29333/EJMSTE/7893

Siron, Y., Wibowo, A., \& Narmaditya, B. S. (2020). Factors Affecting the Adoption of ELearning in Indonesia: Lesson From Covid-19. Journal of Technology and Science Education, 10(2), 282--295-. https://doi.org/10.3926/jotse.1025

Stevens, J. P. (2002). Applied Multivariate Statistics for the Social Sciences. Mahwah, NJ: Lawrence Erlbaum Associates.

Stoltz, P. G. (1997). Adversity Quotient: Turning Obstacles into Opportunities. Canada: John Wiley \& Sons, Inc.

Sumarna, N., Kansil, Y., \& Hamid, R. (2020). The influence of online learning platform models during the COVID-19 outbreak on college student satisfaction levels in 
Southeast Sulawesi. Proceeding International Webinar on Education, (2), 72-81.

Tezer, M., \& Çimşir, B. T. (2018). The impact of using mobile-supported learning management systems in teaching web design on the academic success of students and their opinions on the course. Interactive Learning Environments, 26(3), 402410. https://doi.org/10.1080/10494820.2017.1337037

Wardani, Y., \& Mahmudi, A. (2019). A profile of vocational high school students' adversity quotient towards mathematics. Journal of Physics: Conference Series, 1320(1). https://doi.org/10.1088/1742-6596/1320/1/012062

Wargadinata, W., Maimunah, I., Dewi, E., \& Rofiq, Z. (2020). Student's Responses on Learning in the Early COVID-19 Pandemic. Tadris: Jurnal Keguruan dan Ilmu Tarbiyah, 5(1), 141-153. https://doi.org/10.24042/tadris.v5i1.6153

Zaharah, Z., Kirilova, G. I., \& Windarti, A. (2020). Impact of Corona Virus Outbreak Towards Teaching and Learning Activities in Indonesia. SALAM: Jurnal Sosial dan Budaya Syar-i, 7(3). https://doi.org/10.15408/sjsbs.v7i3.15104 